\title{
Implementation of a Lean Management Approach into a Japanese Company: Impact Analysis
}

Submitted 17/11/21, 1st revision 10/12/21, 2nd revision 05/01/22, accepted 20/02/22

\author{
Abdelhak Benfeddoul ${ }^{1}$, Youssef El Hassani ${ }^{2}$, Abdellatif Eddakir ${ }^{3}$ \\ Hamza Samouche ${ }^{4}$
}

\section{Abstract:}

Purpose: In order to meet both industrial growth and environmental requirements, we have developed in this article an approach for a Lean Management that is interested in reducing waste as well as quality at any level.

Desigh/Methodology/Approach: This approach focuses on the formalization and eval-uation of logistics processes. This method and its implementation on the supply chain of a large multinational in automotive wiring are a guide for organizations wishing to be part of a Lean Management approach. More in details we will make a loop on two factors, on the one hand Lean management practices and Human resources, on the other hand we will the Process of Lean management implementation in production lines at a Japanese company in Automotive Cabling (Supply in terms of components and tubes in production lines).

Findings: The cost reduction, continuous improvement and industries' performance are very important topics for organization all over the world, for this reason several companies have implemented lean management to improve and optimize productivity and quality management systems.

Practical Implementation: The study suggest that in order to success implementation of lean management, companies should focus on two important issues, first human ressources and its impact on changes (internal and external factors), second involve management in supporting teams to understand the practice of this strategy and its positive result for the organization, this is the only way to improve cost reduction in production lines abd the processes for the organization.

Originality value: The assurance of continuous success of the company shows that lean management has become one of the important strategies to implement in order to be more competitive and improve performance.

Keywords: Lean Management, supply chain, quality, stock, consumption, humen resources, cost reduction, performance.

JEL codes: L60, O14, O15.

Research type: Research paper.

${ }^{1}$ Corresponding author, Management, Entrepreneurship and Finance Research and Studies Laboratory, National School of Business and Management, Sidi Mohammed Ben Abdellah University, Fez, Morocco, a.benfeddoul@gmail.com;

${ }^{2}$ The same as in 1 .

${ }^{3}$ The same as in 1 .

${ }^{4}$ Mechanical Engineering Laboratory, Faculty of Science and Techniques, Sidi Mohammed Ben Abdellah University, Fez, Morocco 


\section{Introduction}

Historically, the Lean concept was born at Toyota (Liker, 2004) in the automotive sector but, thanks to its adaptability, it has been applied in various fields of activity, particularly in the military sector and in large companies, for example at Lockheed, Rolls Royce and Boeing, Lean is valued primarily for the tangible benefits it brings (Figure 1 and Figure 2).

Figure 1. Toyota's success in adopting this strategy (Piński and Trębski, 2004)
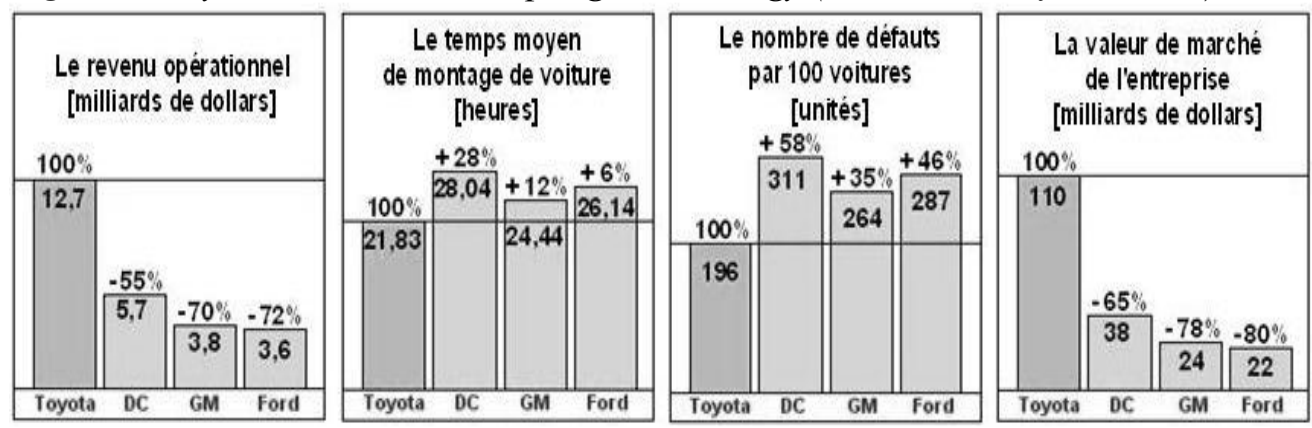

Source: Own research.

Figure 2. History of Lean Management

\begin{tabular}{|c|c|c|c|}
\hline$>1880 s-1920 s$ & $1920 s-1960 s$ & $1960 s-1980 s$ & $1980 s-2010 s$ \\
\hline $\begin{array}{l}\text { Taylorisme } \\
\text { - Division horizontale du } \\
\text { travail : décomposition } \\
\text { du processus de } \\
\text { production en tâches } \\
\text { simples et répétées } \\
\text { - Division verticale du } \\
\text { travail : Distinction des } \\
\text { tâches de définition et de } \\
\text { production }\end{array}$ & $\begin{array}{l}\text { Fordisme } \\
\text { - Apparition de la chaîne } \\
\text { de montage } \\
\text { - Standardisation de la } \\
\text { production («Ford } \mathrm{T} " \text { ) } \\
\text { - Partage des gains de } \\
\text { productivité via une } \\
\text { augmentation des salaires }\end{array}$ & $\begin{array}{l}\text { Toyotisme } \\
\text { - Juste à temps } \\
\text { - Mise en place de } \\
\text { systèmes visuels } \\
\text { - Amélioration permanente } \\
\text { - Association des équipes } \\
\text { à I' identification des } \\
\text { pistes d'amélioration }\end{array}$ & \begin{tabular}{l}
\multicolumn{1}{c}{ LEAN } \\
MANAGEMENT \\
Généralisation des \\
principes du toyotisme \\
à toutes les fonctions \\
et les secteurs \\
d'activité \\
- Limitation des \\
" gaspillages " \\
Multiples outils et \\
méthodologie \\
d'optimisation du \\
temps de production
\end{tabular} \\
\hline
\end{tabular}

\section{Source: Own research.}

As a result, large companies have had to be flexible and adaptable to better position themselves in the international market. In parallel with this market dynamic around the world, companies have adopted Lean Management as a key enabler of their development, however Lean projects have a positive impact on the efficiency and competitiveness of companies as well as organizations. In the Japanese company have a flexible system, reduce development time here are as many requirements of the industry achieved by the lean concept 


\section{Contextualization of Lean Management in the Automotive Industry}

During the last 20 years, many companies chosen to change their strategies and be more competitive in order to take advantage of the apparent economic recovery. Indeed, the Lean Management is one of the best strategies. Before any implementation, these companies tried to answer the following question: Can we produce products that fit perfectly to the expectations of customers, at exceptionally low costs, and of exceptional quality? Two key ideas are at the heart of Lean Management:

- The elimination of all waste throughout the logistics chain and in all business processes. In other words, be economical in the company and not vis-à-vis the customer.

- Put people at the heart of the system by exploiting all intellectual capacities, in all corporate structures, at all levels.

The Lean concept is also being developed in Morocco, which hosts several leading lean companies (Yazaki, Sews, Delphi, Lear, etc.) whose main objective is to ensure a good management system oriented towards the transformation of the radical functioning of the company.

\section{Lean Management Principles}

Lean Management is based on five fundamental principles (Womack and Jones, 1996):

- Defining value from a customer perspective: The basis of this principle is to identify the value perceived by the end customer in terms of the most important characteristics and to analyze the adequacy of the product mix of the organization to the market. The complexity of this principle, which combines notions of marketing with notions of industrial organization, often leads to conflicting perceptions of value between different market segments and even within a segment. The inability to identify exactly the value could result in potentially inefficient operations and especially the establishment of a production system that does not respond to competitive dynamics.

- Value chain identification: It is about identifying all activities across all parts of the organization that provide value to the client in order to highlight activities that do not or do not add value to the process.

- Creating a Lossless Flow: This principle focuses on the design of a process and the establishment of capabilities that allow continuous movement throughout the process without interruption, detour or expectation by eliminating waste.

- Drow production: The aim is to conduct production operations so that supply chains meet demand without overproduction or excessive stock. The aim is to ensure that no activity is carried out before it is required by a swallowing operation. 
- Search for perfection: The elimination of non-added value elements, is a continuous improvement process that must be anchored in a constant approach to improve value specifications and eliminate losses The implementation of Lean Management within a company is based on a toolbox that would improve the efficiency and effectiveness of the supply chain. An overview of the aims related to Lean Management, their definitions and their impacts in Table 1 below.

\section{Characterization of Lean Management}

Lean Management has experienced an exceptional revolution in the industrial sector, and this is due to the potential gains it has brought to companies mainly Japanese, more specifically the automotive sector, the question that arises why this sector also has an interest in applying Lean Management?

The supply chain is made up of several processes, each of which is characterized by a set of operations that consume material and intangible resources, poor management of these can lead to increased costs at all levels. However, there is a consensus that global demand in the automotive industry will continue to increase in the coming years, especially with the covid-19 and after several months of regression the automotive sector has experienced a slight uptake mainly due to a strong demand for purchase of cars in order to avoid any risk of contamination.

This creates increased competition between car manufacturers where everyone will seek to reduce these costs and improve their market share. Moreover, the reduction of these costs can only be achieved through the elimination of non-value-added activities that represent colossal waste (wasted resources, raw materials consumed, etc.) across the chain. That is how we proposed an approach called "Lean Management and companies Performance". Lean Management will focus on making better use of resources with a well-controlled consumption of raw materials while ensuring the importance of the human resources aspect for any success, hence a positive impact on the performance of companies working in the automotive industry.

\section{Lean Management Practices and Human Resources Management}

Lean Management is based on systems and processes, it owes its success to human resources, as it depends in particular on the role that humans can play while ensuring a better understanding of this strategy. It is about changing the culture of the organization in many ways so that it is able to develop continuous quality-based learning and improvement processes. Emphasis should be placed on decentralization of decisions and responsibilities, reversal of hierarchical pyramid, learning processes, leadership and organizational identification to enable a more flexible and responsive organization. 
Table 1. Lean Management aims definitions and impacts

\begin{tabular}{|c|c|c|c|}
\hline $\begin{array}{l}\text { Purpose } \\
\text { of use }\end{array}$ & Tool & Definition & Impact \\
\hline $\begin{array}{l}\text { Value } \\
\text { Chain } \\
\text { Identificat } \\
\quad \text { ion } \\
\text { (Process) }\end{array}$ & $\begin{array}{l}\text { Value Stream } \\
\text { Mapping } \\
\text { (VSM) }\end{array}$ & $\begin{array}{l}\text { MSM is a technique for analyzing and designing the } \\
\text { material and information flows required to make a product } \\
\text { (Frantin, E., 2012). It helps to discriminate between value } \\
\text { added tasks and non-value-added tasks and eliminates } \\
\text { waste }\end{array}$ & $\begin{array}{l}\text { Detect and } \\
\text { eliminate waste }\end{array}$ \\
\hline \multirow{6}{*}{$\begin{array}{l}\text { Creating a } \\
\text { Lossless } \\
\text { Flow } \\
\text { (Process) }\end{array}$} & $\begin{array}{l}\text { Standardizatio } \\
\mathrm{n} \text { of processes }\end{array}$ & $\begin{array}{l}\text { Eclare good practice to do a job (Yingling et al., 2000), in } \\
\text { order to perform the task with the correct practices by } \\
\text { assigning the same workstation to another person }\end{array}$ & $\begin{array}{l}\text { Reducing the } \\
\text { variability of } \\
\text { Process }\end{array}$ \\
\hline & $\begin{array}{l}\text { Productive } \\
\text { Maintenance } \\
\text { (TPM) }\end{array}$ & $\begin{array}{l}\text { Global Productive Maintenance System is a } \\
\text { philosophy that tends to make the technician cooperate } \\
\text { maintenance and operator, where the operator performs an } \\
\text { autonomous maintenance (Wijaya et al., 2009) }\end{array}$ & $\begin{array}{c}\text { Reduce downtime } \\
\text { of } \\
\text { Machines }\end{array}$ \\
\hline & $\begin{array}{l}\text { Single Minute } \\
\text { Change of Die } \\
\text { (SMED) }\end{array}$ & $\begin{array}{l}\text { Organizational Approach to Systematic Reduction series } \\
\text { change time with a quantified objective (Yingling et al. } \\
\text { 2000) }\end{array}$ & $\begin{array}{l}\text { Reduce the time to } \\
\text { change of series }\end{array}$ \\
\hline & $5 \mathrm{~S}$ & $\begin{array}{l}\text { 5S concerns the cleanliness, organization and accessibility } \\
\text { of the workplace (Wijaya et al., 2009). The } 5 \text { Japanese } \\
\text { words mean: Order, Ranger, Dust, Make obvious, Be } \\
\text { rigorous }\end{array}$ & $\begin{array}{l}\text { Ensure a workplace } \\
\text { organized and } \\
\text { accessible }\end{array}$ \\
\hline & $\begin{array}{l}\text { visual } \\
\text { Management } \\
\quad(\mathrm{MV})\end{array}$ & $\begin{array}{l}\text { It makes the evolution of maintenance and production } \\
\text { visible to everyone (Dunstan et al., 2006) }\end{array}$ & $\begin{array}{l}\text { Make visible } \\
\text { the performance } \\
\text { evolution of the } \\
\text { performance }\end{array}$ \\
\hline & JIDOKA & $\begin{array}{l}\text { The Jidoka is synonymous with quality. It forbids to leave } \\
\text { pass a product if it does not meet the specifications of the } \\
\text { client (Dunstan et al., 2006). If there is a problem, the } \\
\text { machine stops automatically by activating a sign that alert } \\
\text { maintenance worker }\end{array}$ & $\begin{array}{l}\text { Stop automatically } \\
\text { the work following } \\
\text { an } \\
\text { anomaly }\end{array}$ \\
\hline \multirow{3}{*}{$\begin{array}{l}\text { Tirer la } \\
\text { productio } \\
\mathrm{n} \\
\text { (Performa } \\
\text { nce) }\end{array}$} & Kanban & $\begin{array}{l}\text { Kanban management is materialized through a containers } \\
\text { and labels between avals and amonts stations. The } \\
\text { objective of the Kanban is to control the production and } \\
\text { eliminate unnecessary stock (Helman, 2012) }\end{array}$ & $\begin{array}{l}\text { Control the } \\
\text { inventory and } \\
\text { eliminate the } \\
\text { unnecessary ones }\end{array}$ \\
\hline & Heijunka & $\begin{array}{l}\text { Heijunka's goal is to achieve the same level of production } \\
\text { every day, which is possible thanks to a skillful } \\
\text { combination of production and orders (Helman, 2012). }\end{array}$ & $\begin{array}{l}\text { Smooth and make } \\
\text { the } \\
\text { regular production }\end{array}$ \\
\hline & $\begin{array}{l}\text { Just in time } \\
\quad(\text { JAT })\end{array}$ & $\begin{array}{l}\text { JAT is a production control system to produce the exact } \\
\text { amount of product required at the time it is necessary. The } \\
\text { objective of the JAT is to ensure balance and } \\
\text { synchronization between the quantity produced and the } \\
\text { demand in eliminating overproduction (Yingling et al., } \\
\text { 2000. }\end{array}$ & $\begin{array}{l}\text { Reduce } \\
\text { inventory }\end{array}$ \\
\hline $\begin{array}{l}\text { Recherche } \\
\text { de la } \\
\text { perfection } \\
\text { (Person) }\end{array}$ & $\begin{array}{l}\text { Involvement } \\
\text { of } \\
\text { the human } \\
\text { being }\end{array}$ & $\begin{array}{l}\text { Encourage the entire hierarchy to contribute to the analysis } \\
\text { problems, the search for solutions and implementation of } \\
\text { improvements (Hattingh and Keys, 2010) }\end{array}$ & $\begin{array}{l}\text { Achieving the } \\
\text { objectives of } \\
\text { the company }\end{array}$ \\
\hline
\end{tabular}

Source: Own research. 
The synergy effect is always sought in an organization adopting Lean Management and this by focusing on interpersonal skills such as communication, information management and collaboration between different stakeholders (internal and external). Thus, the exploitation of technical skills allows the identification of anomalies and the optimization of processes. The company achieves an optimum level of full use of staff skills. In the lean model, it is the people who bring life to the system by working, communicating and participating in problem solving. With a closer look at the model, means that Man is at the heart of activities by identifying anomalies and making suggestions for improvement.

But again, Lean Management encourages, supports and requires employee participation. We should think about the black box of the organization, its knowledge and its know-how. To protect these gains, the company can rely on the stability of its personnel, the gradual and spaced promotion, as well as the carefully studied succession and succession systems.

\section{Process of Implementing Lean Management in Production Lines at a Japanese Company in Atomotive Cabling (Supply in terms or components and tubes in production lines)}

The distributors ensure the physical movement of the full and empty bins between the supermarket and the workstations. Figure 3 shows the physical movement of the raw material between the supermarket and the production lines.

Figure 3. Physical flow of material between the Supermarket and the Production lines

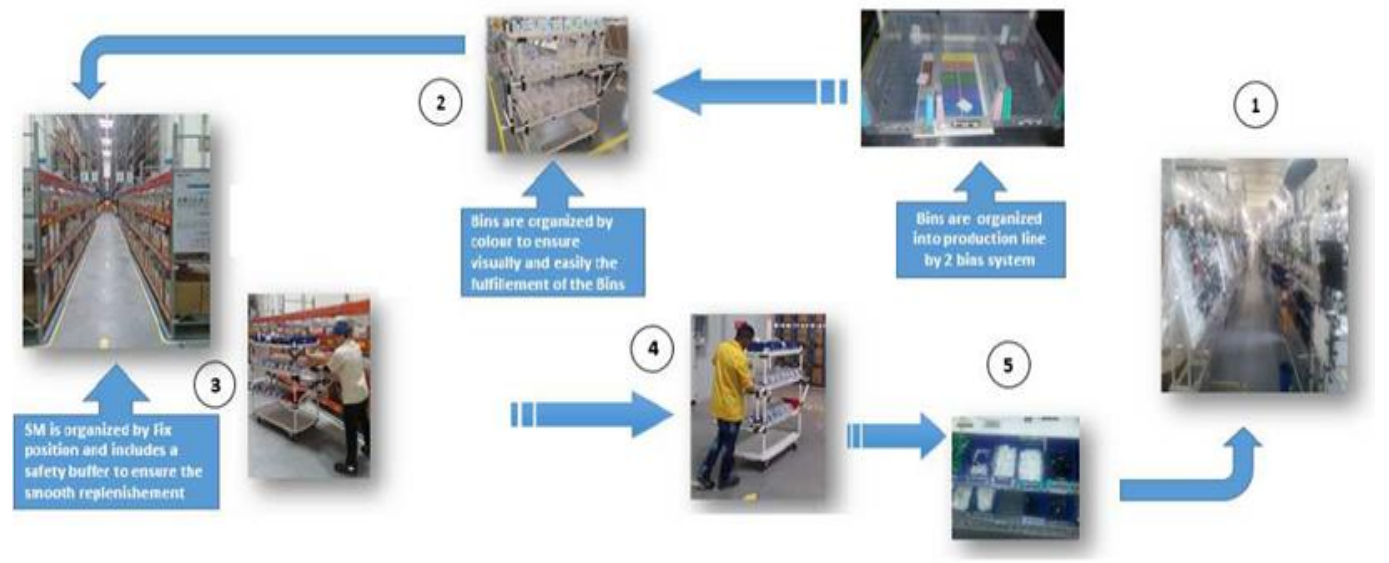

Source: Own research.

Indeed, there are two types of components feeding to the assembly lines:

- $\quad$ Direct feeding from warehouse to production lines (Figure 4).

- $\quad$ Feeding of production lines through the supermarket (Figure 5). 
Figure 4. Direct Feeding to production lines

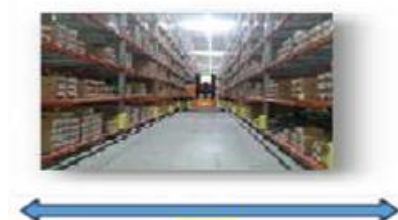

B
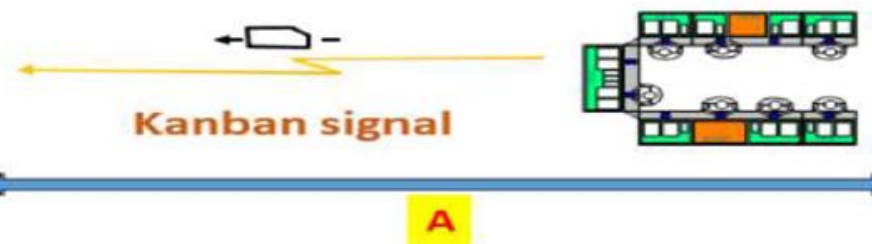

Source: Own research.

Figure 5. Feeding from supermarket to production lines

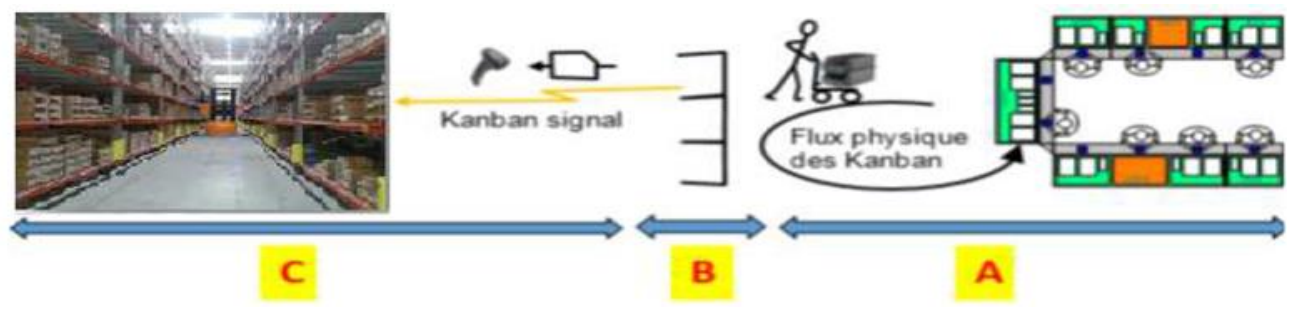

Source: Own research.

In the framework of continuous improvement, the wire harness companies aim to reduce costs, minimize production outstanding as well as increase the quality of products ..., for this and to better achieve the objectives, it is essential to think of several points:

- Standardization of distributors work,

- Minimization of lost time,

- Improving the efficiency and occupancy of distributors,

- Improving the efficiency and occupancy of distributors,

- Creating an optimal model for improving the feeding process,

- The realization of an application that calculates each time the number of optimal distributors,

- A study to implement a new trolley to improve the distribution process as well as the working progress,

- The study related to the distribution of raw material in the supermarket and space management.

Two main objectives were developed, first the flow of distributors, the second related to the capacity of feeding trolleys:

\section{$>$ Distributors flow in production lines}

In a shift (8 hours), the distributor performs two cycles, in each 4 hours, means twice in his day working. However, it was found during the monitoring of the distribution 
of the raw material, that it makes several unnecessary movements things that have a negative impact on each action with an added value in its cycle. A timing of the different actions of the distributor is essential to measure the time of each operation and give an estimation of the time lost that could be exploited otherwise (We took the S2S Project as model of this study) (Table 2):

Table 2. Components distributors in $S 2 S$ project

\begin{tabular}{|c|c|c|c|}
\hline \multirow{2}{*}{\multicolumn{2}{|c|}{$\begin{array}{l}\text { Components distributors in } \quad \mathrm{S} 2 \mathrm{~S} \text { project } \\
\text { (Assembly lines) }\end{array}$}} & \multicolumn{2}{|l|}{ Shift } \\
\hline & & Cycle1 (Min) & \multirow{2}{*}{\begin{tabular}{|l|} 
Cycle 2 (Min \\
$00: 16: 57$ \\
\end{tabular}} \\
\hline \multirow{2}{*}{$\begin{array}{l}\text { Picking up } \\
\text { empty plastic } \\
\text { boxes }\end{array}$} & Components & 00:08:46 & \\
\hline & Tubes & $00: 25: 06$ & 00:32:01 \\
\hline Checks & $\begin{array}{l}\begin{array}{l}\text { Volume (Original carton } \\
\text { boxes) }\end{array} \\
\end{array}$ & $00: 10: 17$ & 00:07:54 \\
\hline \multirow{3}{*}{$\begin{array}{l}\text { Full plastic } \\
\text { boxes feeding }\end{array}$} & Components & $00: 23: 39$ & $00: 26: 17$ \\
\hline & Tubes & 00:45:03 & 00:32:40 \\
\hline & \begin{tabular}{|l}
$\begin{array}{l}\text { Volume } \\
\text { boxes) }\end{array}$ \\
(Original carton
\end{tabular} & $00: 34: 17$ & $00: 27: 48$ \\
\hline \multicolumn{2}{|c|}{ Moving the trolleys } & $00: 16: 14$ & $00: 18: 47$ \\
\hline \multicolumn{2}{|l|}{ Sum $(\mathrm{h})$} & $02: 43: 22$ & 02:42:24 \\
\hline \multicolumn{2}{|l|}{ Total } & $05: 29: 46$ & \\
\hline
\end{tabular}

Source: Own research.

From Table 2 we observe that the distributor in the two cycles of the shift ( 8 hours) work just $5 \mathrm{~h} 29 \mathrm{~min}$, for this and to better understand the situation we calculated the productivity of the distributor as follows:

$$
\text { Productivity }=\frac{\text { operating time }}{\text { Rquired time }}
$$

Based on the result of the timing, in a shift the operating time of the distributor is the sum of the value-added times. The time of the shift should be considered 8 hours, the breaks (20 minutes) the meetings ( $5 * 2$ minutes):

\begin{tabular}{|l|l|l|}
\hline Break time + Communication & $00: 25: 00$ & $00: 25: 00$ \\
\hline
\end{tabular}

Therefore :

$$
\text { Productivity }=\frac{5.29 * 60}{(8 * 60)-((20)+(5 * 2)}
$$

Distributor productivity $=70.53 \%$

This result shows that the productivity of the distributors is $70.53 \%$, means that he does tasks out of his job that can be considered as anomalies or waste of time (we are talking about Muda). 
Based on the observations in the shop floor we have a set of things that leads to the non-productivity of the distributor and the waste of time:

- Feeding of the inappropriate plastic boxes (not respect the coverage of 4 hours production), also feeding of some workstation with difficulty,

- Not defined path to ensure feeding on time,

- Feeding to production lines not well organized.

The result in terms of costs:

The cost of the distributor: $1.85 € / \mathrm{H}$

Time with no added value or time lost is $8 \mathrm{~h} *(1-0.70)=2.4 \mathrm{~h}$

Three shifts a day and the company works 24 days a month

Therefore: Annual loss $=1.85 * 2.4 * 3 * 24 * 12=3837 €$.

These results insist on reorganizing the operations of the distribution cycle in order to exploit non-value-added time and improve the productivity of distributors while standardizing their work and eliminating all sources causing wasted time and random movements

\section{Distribution flow optimization by introducing AGV technology}

Automated Guided Vehicle (AGV) is an automatic self-guided trolley system involving the use of autonomous vehicles without personnel. These industrial vehicles safely transport a multitude of products without requiring human intervention in production, storage, distribution and shipping environments.

The principle of operation of the AGV is to move the loaded trolleys from the supermarket to the production lines or from the lines to the supermarket by following a well-defined route through defined points of each area. Automation of moving trolleys is to reduce the number of distributors, the new distribution of distributors will be as follows:

- 1 distributor will ensure the distribution of volumes by carton boxes;

- 1 distributor will ensure the distribution for smalls families.

The AGV will move the trollies as follows:

- Move the trolleys filled with empty bins from the production lines to the supermarket after the collection of the empty boxes by the polyvalent.

- Move the trolleys from the supermarket to the production lines after filling the boxes in the supermarket.

The polyvalent of each production line should ensure the distribution of components twice per shift (every 4h). 
We calculated the distance travelled in each path, then we summed the distances to get the distance per cycle (Table 3):

Table 3. Distance per cycle

\begin{tabular}{|c|c|c|c|}
\hline & & Distance Covered & $\begin{array}{l}\text { Distance per } \\
\text { cycle }\end{array}$ \\
\hline Go 1 & B Empty & 81,4 & \multirow{2}{*}{181,6} \\
\hline Return 1 & A Full & 100,2 & \\
\hline Go 2 & C Empty & 100,2 & \multirow{2}{*}{181,6} \\
\hline Return 2 & B Full & 81,4 & \\
\hline Go 3 & A Empty & 119 & \multirow{2}{*}{181,6} \\
\hline Return 3 & C Full & 62,6 & \\
\hline Go 1 & B Empty & 72 & \multirow{2}{*}{162,8} \\
\hline Return 1 & A Full & 90,8 & \\
\hline Go 2 & C Empty & 90,8 & \multirow{2}{*}{162,8} \\
\hline Return 2 & B Full & 72 & \\
\hline Go 3 & A Empty & 109,6 & \multirow{2}{*}{162,8} \\
\hline Return 3 & C Full & 53,2 & \\
\hline
\end{tabular}

Source: Own research.

\section{Distance Covered by the AGV}

The total distance covered by the AGV for four hours is $1033.2 \mathrm{~m}$. The number of cycles for the AGV is 6 (1 trolley for 2 lines except Smalls families), so the time cycle of the AGV per cycle is: $240 / 6=40 \mathrm{~min}$. We calculated also the change time of the empty/full trolley in the supermarket by $2 \mathrm{~min}$ and the time of AGV operations per cycle is $0.33 \mathrm{~min}$. So, the $\mathrm{AGV}$ time cycle is $37.67 \mathrm{~min}$

Then we calculated the speed of the AGV:

$$
\mathrm{V}=\frac{\mathbf{D}(\text { Distance covered })}{\mathrm{T}(\text { Time duration })}
$$

$\rightarrow \mathrm{V}=\frac{\mathbf{d}}{\mathbf{t}} \rightarrow \mathrm{V}=0,08 \mathrm{~m} / \mathrm{s}$

\begin{tabular}{|l|l|l|l|l|l|l|}
\hline $\begin{array}{l}\text { Number } \\
\text { of Cycles }\end{array}$ & $\begin{array}{l}\text { Cycle } \\
\text { time } \\
(\mathrm{min})\end{array}$ & $\begin{array}{l}\text { AGV Operations } \\
\text { Time per Cycle } \\
(\mathrm{min})\end{array}$ & $\begin{array}{l}\text { Empty/Full } \\
\text { Trolley Change } \\
(\mathrm{min})\end{array}$ & $\begin{array}{l}\text { CT } \\
\text { AGV } \\
(\mathrm{min})\end{array}$ & $\begin{array}{l}\text { Distance } \\
\text { covered per } \\
\text { cycle }(\mathrm{m})\end{array}$
\end{tabular}$\quad$\begin{tabular}{l}
$\begin{array}{l}\text { AGV } \\
\text { speed } \\
(\mathrm{m} / \mathrm{s})\end{array}$ \\
\hline 6
\end{tabular}

This speed will allow us to respect the time cycle of the power supply of every $4 \mathrm{~h}$, and to standardize the collection time of empty bins, the time of their filling in the supermarket as well as the time of feeding bins filled by the polyvalent, besides of 
this it will minimize the number of distributors things that will impact directly the performance of the company at all levels.

\section{Conclusion}

This study covered potential benefits of Lean Management in supply chains as, cost reduction and value creation, particularly related to raw material process distribution and distributors performance. Lean Management can provide several advantages in supply chain management through improve feeding to production lines and standardize works.

There have been important implementations conducted by Japanese companies as the one of AGV are perfect and can eliminate many errors in the supply chains. This case study shows that choosing the right technology and environment is a critical decision for companies to gain the most out of lean management strategy. Furthermore, it indicates that employing some new technologies will help in implementing of lean management and its concept on supply chain things that will impact positively the global performance of the company.

\section{References:}

Dunstan, K., Lavin, B., Sanford, R. 2006. The application of lean manufacturing in mining environment. International Mine Management Conference.

Frantin, E. 2012. La démarche Lean Méthode. Exemples, Simulations.

Hattingh, T.S., Keys, O.T. 2010. How applicable is industrial engineering in mining? The 4th International Platinum Conference, Platinum in transition 'Boom or Bust'. The Southern African Institute of Mining and Metallurgy

Helman, J. 2012. Analysis of the potentials of adapting elements of Lean Methodology to the unstable conditions in the mining industry. AGH Journal of Mining and Geoengineering, 151-157.

Liker, J.K. 2004. The Toyota way - 14 management principles from the world's greatest manufacturer. McGraw-Hill, New York.

Piński, A., Trębski, K., Uczeń K. 2004. Toyota przerósł trzech wielkich nauczycieli Detroit. Wprost $\mathrm{n}^{\circ} 10$ 50-54, 70-78, 171-172.

Yingling, J.C., Detty, R.B., Sottile, J.J. 2000. Lean Manufacturing Principles and their Applicability to the Mining Industry. Mineral Resources Engineering, 9(2), 215238. https://doi.org/10.1142/S0950609800000184.

Wijaya, A., Kumar, R., Kumar, U. 2009. Implementing Lean Principle into Mining Industry Issues and Challenges. International Symposium on Mine Planning and Equipment Selection. 